\title{
Structural Characterization and Theoretical Calculations of cis-Dioxo(N-salicylidene-2- aminophenolato)(ethanol)molybdenum(VI) complexes MoO2(SAP)(EtOH) (SAP = N-salicylidene-2 aminophenolato)
}

\begin{tabular}{|r|l|}
\hline Journal: & Zeitschrift für Anorganische und Allgemeine Chemie \\
\hline Manuscript ID: & zaac.200900185.R1 \\
\hline Wiley - Manuscript type: & Article \\
\hline Date Submitted by the & 28-May-2009 \\
\hline Complete List of Authors: & $\begin{array}{l}\text { Agustin, Dominique; Université Paul Sabatier, IUT A / Département } \\
\text { de Chimie } \\
\text { Bibal, Christine; Université Paul Sabatier, IUT A / Chemistry } \\
\text { Department } \\
\text { Neveux, Benjamin; Université Paul Sabatier, IUT A / Chemistry } \\
\text { Department } \\
\text { Daran, Jean-Claude; CNRS, Laboratoire de Chimie de Coordination } \\
\text { Poli, Rinaldo; CNRS, Laboratoire de Chimie de Coordination }\end{array}$ \\
\hline $\begin{array}{l}\text { Keywords: } \\
\text { Figure 6.cdx }\end{array}$ & $\begin{array}{l}\text { Molybdenum, X-ray crystallography, Theoretical calculations, Schiff } \\
\text { bases, Tridentate ligands }\end{array}$ \\
\hline $\begin{array}{l}\text { Note: The following files were submitted by the author for peer review, but cannot be converted } \\
\text { to PDF. You must view these files (e.g. movies) online. }\end{array}$ \\
\hline \begin{tabular}{l} 
Figure $1 . c d x$ \\
\hline
\end{tabular}
\end{tabular}

\section{S ScholarONE" \\ Manuscript Central}


[a] CNRS; LCC (Laboratoire de Chimie de Coordination); Université de Toulouse; UPS, INPT; 205, route de Narbonne, F-31077 Toulouse, France

[b] Université de Toulouse, Université Paul Sabatier, Institut Universitaire de Technologie A, Département de Chimie. Avenue Georges Pompidou, 81104 Castres Cedex, France. E-mail: dominique.agustin@iut-tlse3.fr

[c] Institut Universitaire de France, 103, bd Saint-Michel 75005 Paris, France.

Supporting information for this article is available from the author.

\section{Introduction}

Metal oxides are among the most efficient complexes in catalysis. In terms of molecular catalysts, several complexes have been employed for their peculiar reactivity towards oxo-transfer [1-3]. We are currently interested in molybdenum chemistry [4] since its major role in biological processes has been demonstrated over the last two decades [5]. Molecular dioxomolybdenum(VI) complexes are promising candidates as epoxidation catalysts and furthermore can be easily obtained by standard synthetic procedures [6]. Complexes of type $\mathrm{MoO}_{2} \mathrm{~L}$, L being a tridentate dianionic Schiff base ligand [N-salicylidene-2aminophenolate $\quad\left(\mathrm{SAP}^{2-}\right)$ or $\quad \mathrm{N}$-salicylidene-2aminoethanolate $\left.\left(\mathrm{SAE}^{2-}\right)\right]$ have received great attention and the synthetic access towards these molecules has been reported by several research groups [7-9]. In this theme, the known members of this family can be mononuclear, $\mathrm{MoO}_{2} \mathrm{~L}(\mathrm{D})$, stabilized by a donor molecule $\mathrm{D}$ such as an appropriate solvent, or dinuclear containing a double oxygen bridge (i.e. $\left[\mathrm{MoO}_{2} \mathrm{~L}\right]_{2}$ ).
The formation of either of these species strongly depends on the nature of the ligand $\mathrm{L}$ that surrounds the metal centre, the choice of solvent, the presence of other donor molecules $\mathrm{D}$, and the product isolation conditions.

For example, Rajan and Chakravorty [7] reported the thermal conversion of the complex $\mathrm{MoO}_{2} \mathrm{~L}(\mathrm{D})(\mathrm{L}=\mathrm{SAE}$, $\mathrm{SAP}$, and their peripheral-substituted analogues) to $\left[\mathrm{MoO}_{2} \mathrm{~L}\right]_{2}$ (see Fig. 1) The authors described that in order to isolate the complex $\mathrm{MoO}_{2}(\mathrm{SAP})(\mathrm{EtOH})$ they had to reflux $\mathrm{MoO}_{2}(\mathrm{acac})_{2}$ and $\mathrm{SAPH}_{2}$ in ethanol. By this method, no formation of dimeric species was observed $[7,10]$. However, a dimeric species with stoichiometry $\left[\mathrm{MoO}_{2}(\mathrm{SAP})\right]_{2}$ was obtained by heating solid $\mathrm{MoO}_{2}(\mathrm{SAP})(\mathrm{EtOH})$ at $100^{\circ} \mathrm{C}$ under vacuum $[7,11]$. The formation of the oxygen bridge in the resulting $[\mathrm{Mo}(\mathrm{O})(\mu-\mathrm{O})(\mathrm{SAP})]_{2}$ molecule was evidenced by IR spectroscopy with the appearance of an intense band between 800 and $850 \mathrm{~cm}^{-1}$ [12].

A recent report by Cindrić [13] suggests that a monomeric structural analogue of the molybdenum(VI)-SAP species, the complex $\mathrm{MoO}_{2}(\mathrm{SAE})(\mathrm{EtOH})$, can be synthesized by a different procedure. Here, reaction of $\mathrm{MoO}_{2}(\mathrm{acac})_{2}$ with aldehyde and amino-ethanol followed by warming up in a mixture of $\mathrm{CH}_{2} \mathrm{Cl}_{2} / \mathrm{EtOH}(1: 1)$ resulted in formation of the desired product [13]. The described thermal gravimetric analysis (TGA) of $\mathrm{MoO}_{2}(\mathrm{SAE})(\mathrm{EtOH})$ indicated that the coordinating ethanol molecule is very labile (loss between $66^{\circ} \mathrm{C}$ and $83^{\circ} \mathrm{C}$ vs. $100^{\circ} \mathrm{C}$ for the corresponding $\mathrm{MoO}_{2}(\mathrm{SAP})(\mathrm{EtOH})$ monomer). 


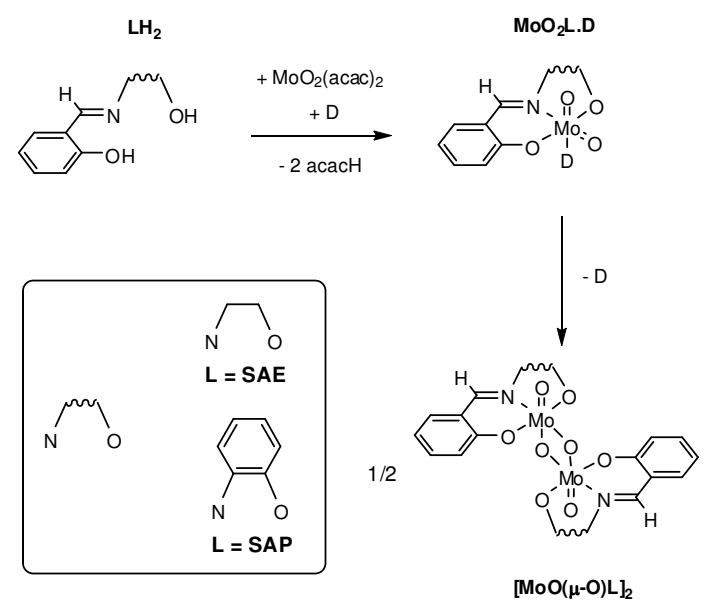

Figure 1. Synthetic routes towards $\mathrm{MoO}_{2} \mathrm{~L} . \mathrm{D}$ and $[\mathrm{Mo}(\mathrm{O})(\mu-\mathrm{O}) \mathrm{L}]_{2}$ complexes $(\mathrm{L}=\mathrm{SAE}$ and $\mathrm{SAP})$

However, following the earlier mentioned experimental procedure by Rajan and Chakravorty in neat ethanol and utilizing the ligand SAE, Sobczak and co-workers reported the direct isolation of dimeric $[\mathrm{Mo}(\mathrm{O})(\mu-\mathrm{O})(\mathrm{SAE})]_{2}$ in solution [12]. The complex was characterized by X-raycrystallography and additionally, IR and Raman spectroscopy data were presented. It is worth mentioning that this dimer can be easily converted back into a mononuclear species, $\mathrm{MoO}_{2}(\mathrm{SAE})(\mathrm{MeOH})$, in refluxing methanol [8].

These observations motivated us to perform calculations on the relative stability in the gas phase between $\mathrm{MoO}_{2} \mathrm{~L}(\mathrm{EtOH})$ and $\left[\mathrm{MoO}_{2} \mathrm{~L}\right]_{2}$ complexes $(\mathrm{L}=\mathrm{SAP}$ and $\mathrm{SAE}$ ) in order to better understand under which conditions monomeric or dimeric species are preferentially formed.

Although $\mathrm{MoO}_{2}(\mathrm{SAP})(\mathrm{EtOH})$ has been already reported in the literature, $[7,10,12,14-16]$ and several $X$-ray structures of substituted- $\mathrm{MoO}_{2}(\mathrm{SAP})(\mathrm{D})$ have been described [17], the Xray structure of the title compound $\mathrm{MoO}_{2}(\mathrm{SAP})(\mathrm{EtOH})$ is presented herein for the first time.

\section{Results and Discussion}

\section{X-ray Diffraction analysis of $\mathrm{MoO}_{2}(\mathrm{SAP})(\mathrm{EtOH})$}

The compound crystallizes in the monoclinic $P 2_{l} / n$ space group (see Table 1). The crystal structure shows the $\mathrm{MoO}_{2}$ (SAP) fragment stabilized by the coordination of one $\mathrm{EtOH}$ molecule (see Figure 2). The $\mathrm{Mo}(1)$ atom is coordinated in octahedral geometry by two cis oxido atoms $\mathrm{O}(3)$ and $\mathrm{O}(4)$, by the SAP ligand with the $\mathrm{N}(1), \mathrm{O}(1)$ and $\mathrm{O}(2)$ atoms occupying meridional positions and finally by the $\mathrm{O}(5)$ atom from the coordinated ethanol molecule. The most significant geometric parameters are collected in Table 2. The Mo-oxido bonds lengths and the $\mathrm{O}(3)-\mathrm{Mo}(1)-\mathrm{O}(4)$ angle between the two Mo-oxido bonds are in agreement with those found for similar $\mathrm{MoO}_{2}$ compounds [17]. The SAP ligand is not planar, the dihedral angle between the two aromatic rings being $9.52^{\circ}$. The $\mathrm{O}(1)-\mathrm{Mo}(1)$ and $\mathrm{O}(2)-$ $\mathrm{Mo}(1)$ bonds corresponding to the O-linkage of molybdenum atom to SAP ligand are respectively 1.972(3) $\AA$ and $1.914(3) \AA$. The shorter Mo-O bond length is related to the six-membered ring. The imine $\mathrm{N}$ is rather loosely bonded to the Mo atom [2.291(4) $\AA$ ] because of the strong trans influence of the $\mathrm{O}(4)$ atom.

In the unit cell, centrosymmetric pseudo-dimers are formed by the establishment of hydrogen bonds between the $\mathrm{H}-\mathrm{O}$ hydrogen of the ethanol molecule of one complex and one oxygen atom $\mathrm{O}(1)$ from the five atom ring of a second complex, as shown in Figure 3. This arrangement is rather typical of small-sized substituted SAP complexes [17]. The $\mathrm{O}(5)^{\cdots} \mathrm{O}(1)^{\prime}$ distance of $2.482(3) \AA$ is in accordance with the existence of hydrogen bonding $[13,17]$.

Table 1. Crystal Structure Data and structure refinement for $\mathrm{MoO}_{2}(\mathrm{SAP})(\mathrm{EtOH})$

\begin{tabular}{|c|c|}
\hline Compound & $\mathrm{MoO}_{2}(\mathrm{SAP})(\mathrm{EtOH})$ \\
\hline Empirical formula & $\mathrm{C}_{15} \mathrm{H}_{15} \mathrm{Mo}_{1} \mathrm{~N}_{1} \mathrm{O}_{5}$ \\
\hline Formula weight & $385.22 \mathrm{~g} / \mathrm{mol}$ \\
\hline$\lambda$ & $0.71073 \AA(\mathrm{MoK} \alpha)$ \\
\hline $\mathrm{T}$ & $296(2) \mathrm{K}$ \\
\hline Crystal System & Monoclinic \\
\hline Space group & $P 2_{1} / n$ \\
\hline A & $11.0923(3) \AA$ \\
\hline B & $6.9590(2) \AA$ \\
\hline $\mathrm{C}$ & $19.4499(5) \AA$ \\
\hline B & $94.4580(10)^{\circ}$ \\
\hline V & $1496.82(7) \AA^{3}$ \\
\hline $\mathrm{Z}$ & 4 \\
\hline$D_{\text {calc }}$ & $1.709 \mathrm{Mg} \cdot \mathrm{m}^{-3}$ \\
\hline Absorption coefficient & $0.899 \mathrm{~mm}^{-1}$ \\
\hline $\mathrm{F}(000)$ & 776 \\
\hline$\theta$ range (min-max) & $3.11^{\circ}-28.31^{\circ}$ \\
\hline Crystal size & $0.10 \times 0.15 \times 0.33 \mathrm{~mm}^{3}$ \\
\hline Index ranges $(\mathrm{h}, \mathrm{k}, \mathrm{l})$ & $\begin{aligned}-14 & \leq \mathrm{h} \leq 14 \\
-9 & \leq \mathrm{k} \leq 9 \\
-25 & \leq 1 \leq 25\end{aligned}$ \\
\hline Reflections collected & 31249 \\
\hline Independent reflections & $3710[\mathrm{R}(\mathrm{int})=0.0381]$ \\
\hline Data / restraints / parameters & $3710 / 0 / 200$ \\
\hline Final $R_{1} / w_{2}[I>2 \sigma(I)]$ & $0.0401 / 0.0862$ \\
\hline Absorption correction & $\begin{array}{l}\text { Semi-empirical from equivalents } \\
(\operatorname{Tmin}=0.654 / \operatorname{Tmax}=1.0)\end{array}$ \\
\hline Goodness-of-fit on $\mathrm{F}^{2}$ & 1.018 \\
\hline Largest diff. peak/hole & 1.825 and $-0.562 \mathrm{e} . \AA^{-3}$ \\
\hline
\end{tabular}

\section{TGA measurements.}

Analyses of the loss of ethanol for $\mathrm{MoO}_{2}(\mathrm{SAP})(\mathrm{EtOH})$ have been reported previously [7,10]. The thermogravimmetric analysis of $\mathrm{MoO}_{2}(\mathrm{SAP})(\mathrm{EtOH})$ has been performed herein using air as gas carrier. The sample was heated at a rate of $0.83^{\circ} \mathrm{C} \mathrm{s}^{-1}$ from $20^{\circ} \mathrm{C}$ to $600^{\circ} \mathrm{C}$. A first endothermic weight loss is observed between $100^{\circ} \mathrm{C}$ and $120^{\circ} \mathrm{C}$, previously assigned [7,10] to the loss of one molecule of ethanol. The experimental mass loss value $\left(\Delta \mathrm{m}_{\mathrm{rel}}=11.80 \%\right)$ agrees with the expected one $\left(\Delta \mathrm{m}_{\mathrm{rel}}=\right.$ $11.96 \%)$. 
Our TGA study has been pushed to much higher temperatures than previously reported, see Figure 4. An exothermic loss observed in the temperature range $280^{\circ} \mathrm{C}$ $550^{\circ} \mathrm{C}$ corresponds to the loss of an organic fragment corresponding to $\left(\mathrm{C}_{13} \mathrm{H}_{9} \mathrm{NO}\right)$, with an experimental value $\left(\Delta \mathrm{m}_{\mathrm{rel}}=51.64 \%\right)$ in accordance with the expected mass loss $\left(\Delta \mathrm{m}_{\mathrm{rel}}=50.68 \%\right)$. Thus, the final product of this thermal decomposition process corresponds to $\mathrm{MoO}_{3}$, which is stable under these conditions [18] (see scheme 1).

$$
\mathrm{MoO}_{2}(\mathrm{SAP})(\mathrm{EtOH}) \stackrel{\Delta,-E t O H}{\longrightarrow} \mathrm{MoO}_{2}(\mathrm{SAP}) \stackrel{\Delta,- \text { (SAP-O) }}{\longrightarrow} \mathrm{MoO}_{3}
$$

Scheme 1. Thermal decomposition of $\mathrm{MoO}_{2}(\mathrm{SAP})(\mathrm{EtOH})$.

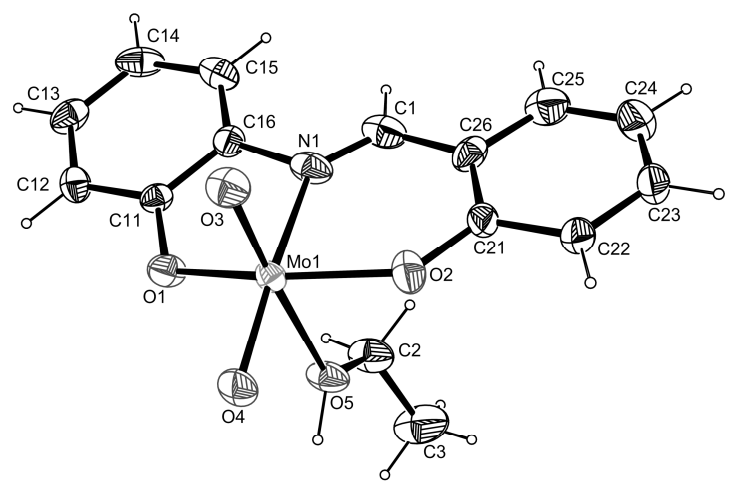

Figure 2. Ortep view of $\mathrm{MoO}_{2}(\mathrm{SAP})(\mathrm{EtOH})$

Table 2 - Relevant crystallographic distances $(\AA)$ and angles $\left(^{\circ}\right)$ of $\mathrm{MoO}_{2}(\mathrm{SAP})(\mathrm{EtOH})$

\begin{tabular}{llll}
\hline Bond lengths & $(\AA)$ & Angles $\left(^{\circ}\right)$ & \\
\hline $\mathrm{Mo}(1)-\mathrm{O}(3)$ & $1.689(3)$ & $\mathrm{O}(3)-\mathrm{Mo}(1)-\mathrm{O}(4)$ & $106.01(15)$ \\
$\mathrm{Mo}(1)-\mathrm{O}(4)$ & $1.695(3)$ & $\mathrm{O}(3)-\mathrm{Mo}(1)-\mathrm{O}(2)$ & $100.35(15)$ \\
$\mathrm{Mo}(1)-\mathrm{O}(1)$ & $1.972(3)$ & $\mathrm{O}(4)-\mathrm{Mo}(1)-\mathrm{O}(2)$ & $101.68(14)$ \\
$\mathrm{Mo}(1)-\mathrm{O}(2)$ & $1.914(3)$ & $\mathrm{O}(3)-\mathrm{Mo}(1)-\mathrm{O}(1)$ & $97.33(14)$ \\
$\mathrm{Mo}(1)-\mathrm{O}(5)$ & $2.370(3)$ & $\mathrm{O}(4)-\mathrm{Mo}(1)-\mathrm{O}(1)$ & $96.02(13)$ \\
$\mathrm{Mo}(1)-\mathrm{N}(1)$ & $2.291(4)$ & $\mathrm{O}(2)-\mathrm{Mo}(1)-\mathrm{O}(1)$ & $150.34(15)$ \\
$\mathrm{C}(1)-\mathrm{N}(1)$ & $1.216(5)$ & $\mathrm{O}(3)-\mathrm{Mo}(1)-\mathrm{N}(1)$ & $91.74(14)$ \\
$\mathrm{C}(1)-\mathrm{C}(26)$ & $1.448(6)$ & $\mathrm{O}(4)-\mathrm{Mo}(1)-\mathrm{N}(1)$ & $160.60(13)$ \\
$\mathrm{C}(2)-\mathrm{O}(5)$ & $1.415(5)$ & $\mathrm{O}(2)-\mathrm{Mo}(1)-\mathrm{N}(1)$ & $82.29(14)$ \\
$\mathrm{C}(11)-\mathrm{O}(1)$ & $1.354(4)$ & $\mathrm{O}(1)-\mathrm{Mo}(1)-\mathrm{N}(1)$ & $73.53(13)$ \\
$\mathrm{C}(16)-\mathrm{N}(1)$ & $1.507(5)$ & $\mathrm{O}(3)-\mathrm{Mo}(1)-\mathrm{O}(5)$ & $172.97(13)$ \\
$\mathrm{C}(21)-\mathrm{O}(2)$ & $1.329(5)$ & $\mathrm{O}(4)-\mathrm{Mo}(1)-\mathrm{O}(5)$ & $80.77(12)$ \\
& & $\mathrm{O}(2)-\mathrm{Mo}(1)-\mathrm{O}(5)$ & $79.75(13)$ \\
& & $\mathrm{O}(1)-\mathrm{Mo}(1)-\mathrm{O}(5)$ & $79.84(12)$ \\
& & $\mathrm{N}(1)-\mathrm{Mo}(1)-\mathrm{O}(5)$ & $81.30(11)$
\end{tabular}

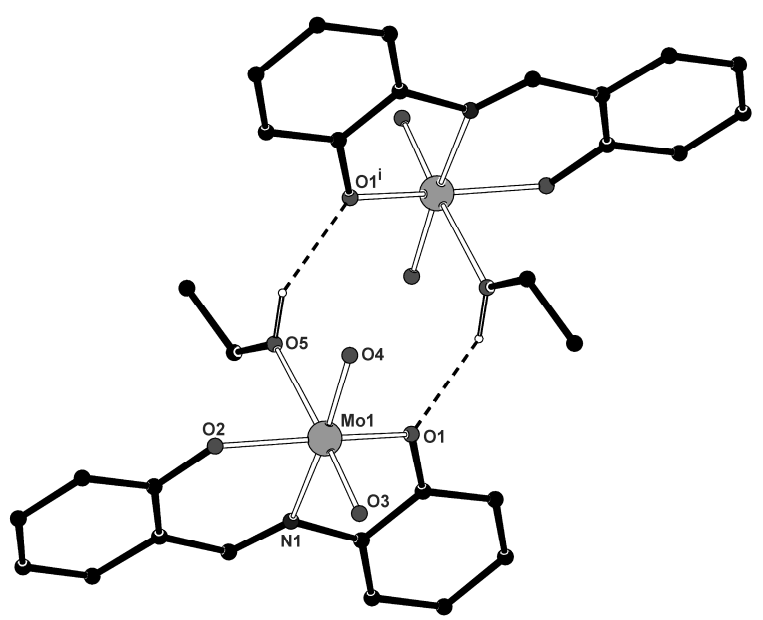

Figure 3. View of a pseudo-dimer formed through hydrogen bonding between two $\mathrm{MoO}_{2}(\mathrm{SAP})(\mathrm{EtOH})$ molecules. Intermolecular hydrogen bonds are represented by dotted lines.

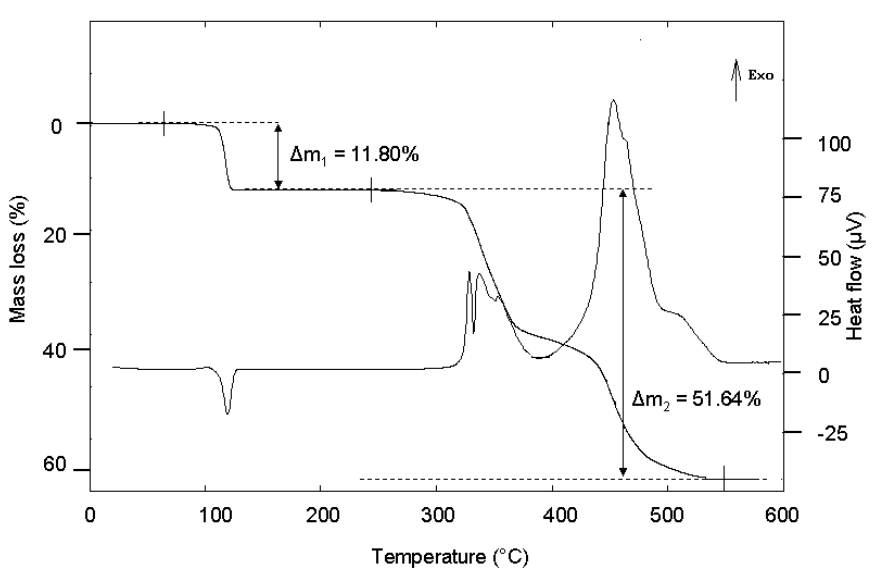

Figure 4. Thermogravimmetric diagram of $\mathrm{MoO}_{2}(\mathrm{SAP})(\mathrm{EtOH})$

$\mathrm{DFT}$ study: relative stability of $\mathrm{MoO}_{2} \mathrm{~L}(\mathrm{EtOH})$ and
$\left[\mathrm{MoO}_{2}(\mathrm{~L})\right]_{2}(\mathrm{~L}=\mathrm{SAP}, \mathrm{SAE})$

As stated above, the relative stabilization of the putative 5-coordinate $\mathrm{MoO}_{2} \mathrm{~L}$ fragment by donor molecules $\mathrm{D}$, forming $\mathrm{MoO}_{2} \mathrm{~L}(\mathrm{D})$, or by dimerization to yield $\left[\mathrm{MoO}_{2} \mathrm{~L}\right]_{2}$ strongly depends on the nature of $\mathrm{L}$ and $\mathrm{D}[7,8]$. With specific reference to the tridentate $(\mathrm{O}, \mathrm{N}, \mathrm{O})$ ligands SAP and SAE, many stable $\mathrm{MoO}_{2} \mathrm{~L}$ (D) compounds are known for both $\operatorname{SAP}$ (e.g. with $\mathrm{D}=\mathrm{MeOH}, \mathrm{H}_{2} \mathrm{O}$, DMSO, amine, imidazoles, ethanol, $\mathrm{SAEH}_{2}$ [7-10,12,14-16,19-21]) and SAE (D = DMF [22], MeOH [23,24], $\mathrm{H}_{2} \mathrm{O}$ [12], EtOH $\left.[13,25], \mathrm{SAEH}_{2}[8,26]\right)$. However, the SAE complexes show a greater tendency to dimerize, as indicated by the lower temperature for ethanol loss in the TGA [13].

In order to evaluate the influence of $\mathrm{L}$ on the relative preference of $\mathrm{MoO}_{2} \mathrm{~L}(\mathrm{EtOH})$, and $\left[\mathrm{MoO}_{2} \mathrm{~L}\right]_{2}$, we have carried out geometry optimizations and calculations of the thermodynamic parameters for both complexes as well as for the solvent-free intermediate $\mathrm{MoO}_{2} \mathrm{~L}$. It has to be 
pointed out that these calculations refer to the ideal gas at $298 \mathrm{~K}$; therefore, they do not take into account solvation effects. The energetic results of the calculations are summarized in Table 3 and depicted in Figure 5. The dimerization process (equation 1) is ideally broken into two steps, the first one being the ethanol decoordination to yield the 5-coordinate $\mathrm{MoO}_{2} \mathrm{~L}$ fragment (equation 2) and the second being dimerization of the latter (equation 3 ).

Table 3 - Calculated enthalpy changes (in $\mathrm{kcal} \mathrm{mol}^{-1}$ ) for the SAP and SAE systems

\begin{tabular}{lcc}
\hline & $\mathrm{L}=\mathrm{SAP}$ & $\mathrm{L}=\mathrm{SAE}$ \\
\hline$\Delta \mathrm{H}^{\mathrm{a}}$ & +9.72 & +6.27 \\
$\Delta \mathrm{H}_{\text {decoordination }^{\mathrm{b}}{ }^{\mathrm{b}}}$ & +9.70 & +10.96 \\
$\Delta \mathrm{H}_{\text {dimerisation }}{ }^{2}$ & -9.69 & -15.66 \\
\hline
\end{tabular}

${ }^{\mathrm{a} E n t h a l p y ~ c h a n g e ~ a s s o c i a t e d ~ t o ~ r e a c t i o n ~} 1 .{ }^{\mathrm{b}}$ Enthalpy change associated to reaction $2 .{ }^{c}$ Enthalpy change associated to reaction 3 .

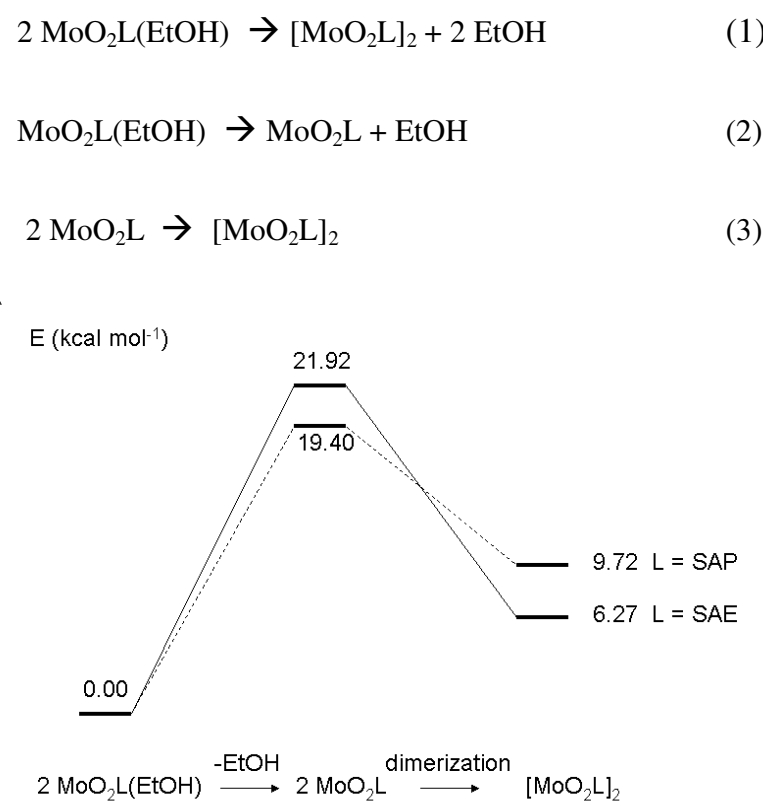

Figure 5. Enthalpy diagram for the conversion of $\mathrm{MoO}_{2} \mathrm{~L}(\mathrm{EtOH})$ to $\left[\mathrm{MoO}_{2} \mathrm{~L}\right]_{2}$ in the gas phase $(\mathrm{L}=\mathrm{SAP}, \mathrm{SAE})$.

Table 4 - Selected bond distances $(\AA)$ and angles $\left({ }^{\circ}\right)$ of the DFT optimized geometries

\begin{tabular}{|c|c|c|c|c|c|c|}
\hline parameter & & $=\mathrm{SAP}$ & & & $=\mathrm{SAE}$ & \\
\hline & $\mathrm{MoO}_{2} \mathrm{~L}(\mathrm{EtOH})$ & $\mathrm{MoO}_{2} \mathrm{~L}$ & {$\left[\mathrm{MoO}_{2} \mathrm{~L}\right]_{2}$} & $\mathrm{MoO}_{2} \mathrm{~L}(\mathrm{EtOH})$ & $\mathrm{MoO}_{2} \mathrm{~L}$ & {$\left[\mathrm{MoO}_{2} \mathrm{~L}\right]_{2}$} \\
\hline $\mathrm{Mo}=\mathrm{O}_{\mathrm{ax}}$ & 1.696 & 1.696 & 1.692 & 1.698 & 1.699 & 1.695 \\
\hline $\mathrm{Mo}=\mathrm{O}_{\mathrm{eq}}$ & 1.703 & 1.696 & 1.741 & 1.712 & 1.700 & 1.755 \\
\hline Mo-O (EtOH) & 2.491 & - & 2.470 & 2.608 & 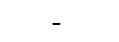 & 2.436 \\
\hline Mo-OPh1 & 1.985 & 1.963 & 1.949 & 1.984 & 1.970 & 1.967 \\
\hline Mo-OPh2 & 1.967 & 1.956 & 1.960 & & & \\
\hline $\mathrm{Mo}-\mathrm{OCH}_{2} \mathrm{CH}_{2}$ & & & & 1.932 & 1.924 & 1.921 \\
\hline Mo-N & 2.348 & 2.345 & 2.309 & 2.319 & 2.322 & 2.290 \\
\hline $\mathrm{O}=\mathrm{Mo}=\mathrm{O}$ & 107.5 & 109.5 & 108.1 & 107.4 & 108.5 & 106.8 \\
\hline $\mathrm{O}_{\mathrm{ax}}-\mathrm{Mo}-\mathrm{O}($ trans $)$ & 174.2 & - & 176.6 & 175.3 & - & 176.7 \\
\hline $\mathrm{O}(\mathrm{L})-\mathrm{Mo}-\mathrm{O}^{\prime}(\mathrm{L})$ & 145.8 & 138.3 & 149.6 & 145.9 & 136.5 & 150.7 \\
\hline $\mathrm{N}-\mathrm{Mo}=\mathrm{O}_{\mathrm{eq}}$ & 159.1 & 152.9 & 154.4 & 156.1 & 155.4 & 151.7 \\
\hline
\end{tabular}

The total energy of the reaction in the gas phase for both ligands is qualitatively coherent with the experimental observations. The enthalpy change is in favour of the mononuclear ethanol-stabilized complex $\mathrm{MoO}_{2} \mathrm{~L}(\mathrm{EtOH})$ in both cases, but more so for the SAP system. Examination of each separate step shows that the SAE system favors the 6coordinate species, both the $\mathrm{EtOH}$ adduct and the dimer, relative to the mononuclear $\mathrm{MoO}_{2} \mathrm{~L}$ fragment to a greater extent than the SAP system. However, whereas ethanol coordination is only mildly more exothermic, dimerization is more exothermic for SAE.

We have analyzed the optimized geometries (shown in Figure 6 with selected bond distances and angles collected in Table 4) more in detail in an attempt to pinpoint the cause of this energetic preference, but no clear factor, electronic or steric, seems to emerge from this analysis. The energy differences are only subtle, thus this analysis is not devoid of ambiguity. The most evident structural difference is the Mo-O (EtOH) distance, which is more than $0.1 \AA$ longer in the SAE derivative, in apparent contradiction with the more favourable binding enthalpy. One conclusion that appears quite certain is that $\mathrm{EtOH}$ on one side and dimerization on the other side do not greatly perturb the coordination 
geometry of the $\mathrm{MoO}_{2} \mathrm{~L}$ moiety, in agreement with the small energy changes associated to these interactions.

\section{Conclusions}

The X-ray structure of $\mathrm{MoO}_{2}(\mathrm{SAP})(\mathrm{EtOH})$ is reported here for the first time. The energetic preference between mononuclear $\mathrm{MoO}_{2} \mathrm{~L}(\mathrm{EtOH})$ and dinuclear $\left[\mathrm{MoO}_{2} \mathrm{~L}\right]_{2}$ has been studied by DFT in the gas phase for $\mathrm{L}=\mathrm{SAP}$ and SAE. The greater propensity of the SAE system to yield the dinuclear product is reproduced by the calculations.

\section{Experimental Section}

Materials. All experiments were carried out in air. Absolute ethanol and distilled water were used as solvents. $\mathrm{MoO}_{2}(\mathrm{acac})_{2}$ was purchased (Aldrich) and stored under a nitrogen atmosphere before use. $\mathrm{MoO}_{2}(\mathrm{SAP})(\mathrm{EtOH})$ was obtained according to the literature procedures.[7]

IR spectra. Infrared spectra were recorded on $\mathrm{KBr}$ pellets at room temperature with a Mattson Genesis II FTIR spectrometer.

TGA measurements. The thermogravimetric analysis was performed on a SETARAM TGA 92-16.18 thermal analyzer. The sample was placed into a nickel/platinum alloy crucible and heated at $0.83 \mathrm{~K} \mathrm{~s}^{-1}$ in a reconstituted air flow from $20^{\circ} \mathrm{C}$ to $600^{\circ} \mathrm{C}$. An empty crucible was used as a reference.

Synthesis of $\mathbf{S A P H}_{2}$. Compound $\mathrm{SAPH}_{2}$ was obtained by mixing $1.1 \mathrm{~mL}(10 \mathrm{mmol})$ of salicylaldehyde and $1.09 \mathrm{~g}(10 \mathrm{mmol})$ of $o-$ aminophenol in $30 \mathrm{~mL}$ of distilled water. The mixture was stirred for two hours at room temperature yielding a red precipitate. The compound was separated by filtration, dried and recrystallized from ethanol. The red solid (61\%) was then filtered off and dried. The purity was checked by IR and NMR spectroscopy.

Crystallization of $\mathrm{MoO}_{2}(\mathbf{S A P})(\mathbf{E t O H})$. The complex was synthesized using the know procedures using $\mathrm{MoO}_{2}$ (acac) $)_{2}$ and $\mathrm{SAPH}_{2}$ in boiling ethanol.[7] The crude precipitate was separated by filtration and recrystallized three times with hot ethanol, yielding orange crystals. The IR and NMR properties corresponded with those previously reported. [7, 12]

Synthesis of $\left[\mathrm{MoO}_{2}(\mathrm{SAP})\right]_{2}$. Several ways can be used for the obtention of $\left[\mathrm{MoO}_{2}(\mathrm{SAP})\right]_{2}$. The compound can be prepared by heating under vacuum or by letting the crystals of $\mathrm{MoO}_{2}(\mathrm{SAP})(\mathrm{EtOH})$ stand in air for a long period [7,11]. The orange crystals turn to the brown color of $\left[\mathrm{MoO}_{2}(\mathrm{SAP})\right]_{2}$. IR $\left(\mathrm{cm}^{-1}\right.$, $\mathrm{KBr}$ pellets): $941(\mathrm{Mo}=\mathrm{O}), 820$ (Mo-O-Mo). TGA $\left(20-600^{\circ} \mathrm{C}\right.$, $\left.0.83{ }^{\circ} \mathrm{C} / \mathrm{min}\right) \Delta \mathrm{m}_{\text {exp }}=58.57 \%\left(\Delta \mathrm{m}_{\text {theo }}=57.55 \%\right)$.

\section{Computational details.}

The geometries of all species under investigation were optimized without any symmetry constraint with the Gaussian 03 [27] program suite. The input geometries were adapted from the X-ray structures of $\mathrm{MoO}_{2}(\mathrm{SAP})(\mathrm{EtOH})$ (reported here) and $\left[\mathrm{MoO}_{2}(\mathrm{SAE})\right]_{2}[8]$,. The calculations used the standard B3LYP three-parameter functional, in conjunction with the $6-31 \mathrm{G}^{* *}$ basis set for $\mathrm{C}, \mathrm{H}, \mathrm{N}$ and $\mathrm{O}$ atoms and with the CEP-31G* basis set for Mo. All optimized geometries were confirmed to be local minima by frequency analyses, which were also used to derive the thermochemical parameters at $298 \mathrm{~K}$ according to the standard ideal gas approximation. (Optimized cartesian coordinates are available as supplementary material from the author)

\section{X-ray crystallography}

A single crystal of compound $\mathrm{MoO}_{2}(\mathrm{SAP})(\mathrm{EtOH})$ was mounted under inert perfluoropolyether on the tip of a glass fibre and cooled in the cryostream of a Bruker APEXII-II diffractometer. Data were collected using the monochromatic MoK $\alpha$ radiation $(\lambda=0.71073)$. The structure was solved by direct methods (SIR97) [28] and refined by least-squares procedures on $F^{2}$ using SHELXL-97.[29] All $\mathrm{H}$ atoms attached to carbon were introduced in idealised positions and treated as riding models in the calculations. The drawing of the molecule was realised with the help of ORTEP3. [30] Crystal data and refinement parameters are shown in Table 1. Crystallographic data (excluding structure factors) have been deposited with the Cambridge Crystallographic Data Centre as supplementary publication no. CCDC 721853. Copies of the data can be obtained free of charge on application to the Director, CCDC, 12 Union Road, Cambridge CB2 1EZ, UK (fax: (+44) 1223-336-033; e-mail: deposit@ ccdc.cam.ac.uk).

\section{Acknowledgments}

We thank the CNRS and the Université Paul Sabatier (IUT A, Chemistry Dept in Castres) for support, and the Centre Interuniversitaire de Calcul de Toulouse (CICT, project CALMIP) for computational time.

\section{[1] R. H. Holm, Chem. Rev. 1987, 87, 1401-1449.}

[2] W.-S. Jung, H.-Y. Moon, Y.-Y. Park, Polyhedron, 1997, 16, 2169-2173.

[3] J. Topich, J. O. Bachert, Inorg. Chem., 1992, 31, 511-515.

[4] (a) R. Poli, Coord. Chem. Rev. 2008, 252, 1592-1612. (b) R. Poli Chem.-A Eur. J, 2004, 10, 332-341.

[5] A. G. Wedd, Coord. Chem. Rev. 1996, 154, 5-11.

[6] For epoxidation reactions with dioxidomolybdenum complexes, see recent references. (a) S. M. Bruno, S. S. Balula, A. A. Valente, F. A. Almeida Paz, M. Pillinger, C. Sousa, J. Klinowski, C. Freire, P. Ribeiro-Claro, I. S. Goncalves, J. Mol. Catal. A: Chem 2007, 270, 185-194. (b) S. M. Bruno, J. A. Fernandes, L. S. Martins, I. S.; Goncalves, M. Pillinger, P. Ribeiro-Claro, J. Rocha, A. A. Valente, Catal. Today 2006, 114, 263-271. (c) X. Zhou, Xiangge; J. Zhao, A. M. Santos, F. E. Kuehn, Z. Naturforsch, B: J. Chem. Sci 2004, 59, 1223-1228. (d) J. Fridgen, W. A. Herrmann, G. Eickerling, A. M. Santos, F. E. Kuehn, J. Organomet. Chem. 2004, 689, 2752-2761. (e) J. Zhao, X. Zhou, A. M. Santos, E. Herdtweck, C. C. Romao, F. E. Kuehn, Dalton Trans. 2003, 19, 3736-3742.

[7] O. A. Rajan, A. Chakravorty, Inorg. Chem. 1981, 20, 660664.

[8] T. Głowiak, L. Jerzykiewicz, J. M. Sobczak, J. J. Ziółkowski, Inorg. Chim. Acta, 2003, 356, 387-392.

[9] C. Zhang, G. Rheinwald, V. Lozan, B. Wu, P.-G. Lassahn, H. Lang, C. Janiak, Z. Anorg. Allg. Chem. 2002, 628, 1259-1268.

[10] P. K. Nath,, K. C. Dash, Transition Met. Chem. 1985, 10, 262-264.

[11] J. U. Mondal, F. A. Schultz, T. D. Brennan, W. R. Scheidt, Inorg. Chem. 1988, 27, 3950-3956.

[12] J. M. Sobczak, T. Głowiak, J. J. Ziółkowski, Transition Met. Chem., 1990, 15, 208-211.

[13] M. Cindrić, N. Strukan, V. Vrdoljak, T. Kajfež, B. Kamenar Z. Anorg. Allg. Chem. 2002, 628, 2113-2117.

[14] W.-S. Jung, H.-Y. Moon, Y.-Y. Park, Polyhedron, 1997, 16, 2169-2173.

[15] J. Topich, Inorg. Chim. Acta 1980, 46, L37-L39. 
[16] J. Topich, Inorg. Chem, 1981, 20, 3704-3707.

[17] M. Cindrić, N. Strukan, V. Vrdoljak, B. Kamenar, Z. Anorg. Allg. Chem. 2004, 630, 585-590.

[18] K. Andjelković, M. Šumar, I. Ivanović-Burmazović, J. Therm. Anal. Calorim. , 2001, 66, 759-768.

[19] A. Syamal, M. R. Maurya, Coord. Chem. Rev., 1989, 95, 183-238.

[20] J. M. Sobczak, J. J. Ziółkowski, Appl. Cat. A: Gen., 2003, $248,261-268$.

[21] D. D. Agarwal, S. Shrivastava, Polyhedron, 1988, 7, 25692573.

[22] V. S. Sergienko, V. L. Abramenko, M. A. Porai-Koshits, A. D. Garnovskii, Zh Strukt Khim 1990, 31, 54-60

[23] M. Minelli, F. Namuswe, D. Jeffrey, A.-L. Morrow, I. A. Guzei, D. Swenson, E. Bothe, T. Weyhermueller, Inorg. Chem. 2006, 45, 5455-5464.

[24] R. N. Mohanty, V. Chakravortty, K. C. Dash, Polyhedron 1991, 10, 33-35

[25] M. A. Salam, M. Alauddin, A. Islam, J Bangladesh Chem Soc 1993, 6(1), 57-63.

[26] D. Agustin, J.-C. Daran et R. Poli, Acta Crystallogr. Sect. C: Cryst.; Struct. Commun. 2008, C64, m101-m104.

[27] Gaussian 03, Revision D.01, M. J. Frisch, G. W. Trucks, H. B. Schlegel, G. E. Scuseria, M. A. Robb, J. R. Cheeseman, J. A. Montgomery, Jr., T. Vreven, K. N. Kudin, J. C. Burant, J. M. Millam, S. S. Iyengar, J. Tomasi, V. Barone, B. Mennucci, M. Cossi, G. Scalmani, N. Rega, G. A. Petersson, H. Nakatsuji, M. Hada, M. Ehara, K. Toyota, R. Fukuda, J. Hasegawa, M. Ishida, T. Nakajima, Y. Honda, O. Kitao, H Nakai, M. Klene, X. Li, J. E. Knox, H. P. Hratchian, J. B. Cross, V. Bakken, C. Adamo, J. Jaramillo, R. Gomperts, R. E. Stratmann, O. Yazyev, A. J. Austin, R. Cammi, C. Pomelli, J. W. Ochterski, P. Y. Ayala, K. Morokuma, G. A. Voth, P. Salvador, J. J. Dannenberg, V. G. Zakrzewski, S Dapprich, A. D. Daniels, M. C. Strain, O. Farkas, D. K. Malick, A. D. Rabuck, K. Raghavachari, J. B. Foresman, J. V. Ortiz, Q. Cui, A. G. Baboul, S. Clifford, J. Cioslowski, B. B. Stefanov, G. Liu, A. Liashenko, P. Piskorz, I. Komaromi, R. L. Martin, D. J. Fox, T. Keith, M. A. Al-Laham, C. Y Peng, A. Nanayakkara, M. Challacombe, P. M. W. Gill, B. Johnson, W. Chen, M. W. Wong, C. Gonzalez, and J. A. Pople, Gaussian, Inc., Wallingford CT, 2004.

[28] A. Altomare, M. Burla, M. Camalli, G. Cascarano, C. Giacovazzo, A. Guagliardi, A. Moliterni, G. Polidori, R. Spagna, J. Appl. Crystallogr. 1999, 32, 115-119.

[29] G. M. Sheldrick, SHELXL97. Program for Crystal Structure refinement, University of Göttingen, Göttingen, Germany, 1997.

[30] L. J. Farrugia, J. Appl. Crystallogr. 1997, 32, 565

Received: ((will be filled in by the editorial staff)) Published online: ((will be filled in by the editorial staff) 
5

6
7

8

9

10

11

12

13

14

15

16

17

18

19

21

22

23

24

25

26

27

29

30

31

32

33

34

35

36

37

38

39

40

41

42

43

44

45

46

47

48

49

50

51

52

53

54

55

56

58

59 


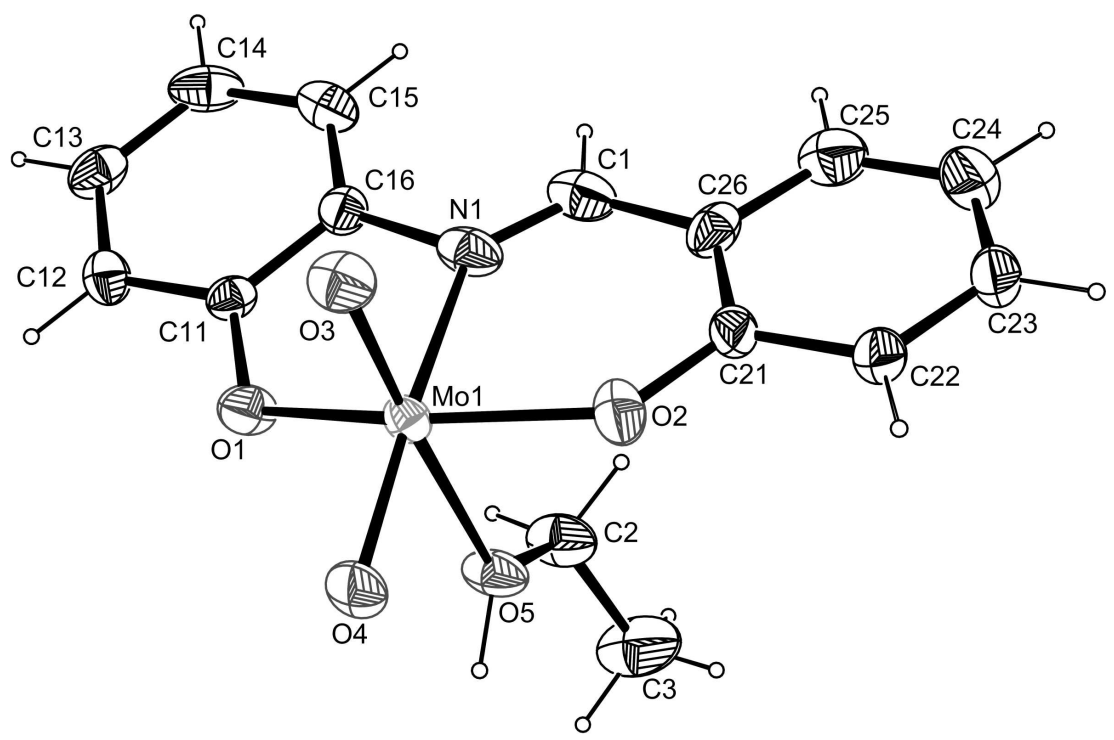

Figure 2. Ortep view of $\mathrm{MoO}_{2}(\mathrm{SAP})(\mathrm{EtOH})$ $120 \times 80 \mathrm{~mm}(600 \times 600 \mathrm{DPI})$ 
1

2

3

4

5

6

7

8

9

10

11

12

13

14

15

16

17

18

19

20

21

22

23

24

25

26

27

28

29

30

31

32

33

34

35

36

37

38

39

40

41

42

43

44

45

46

47

48

49

50

51

52

53

54

55

56

57

58

59

60

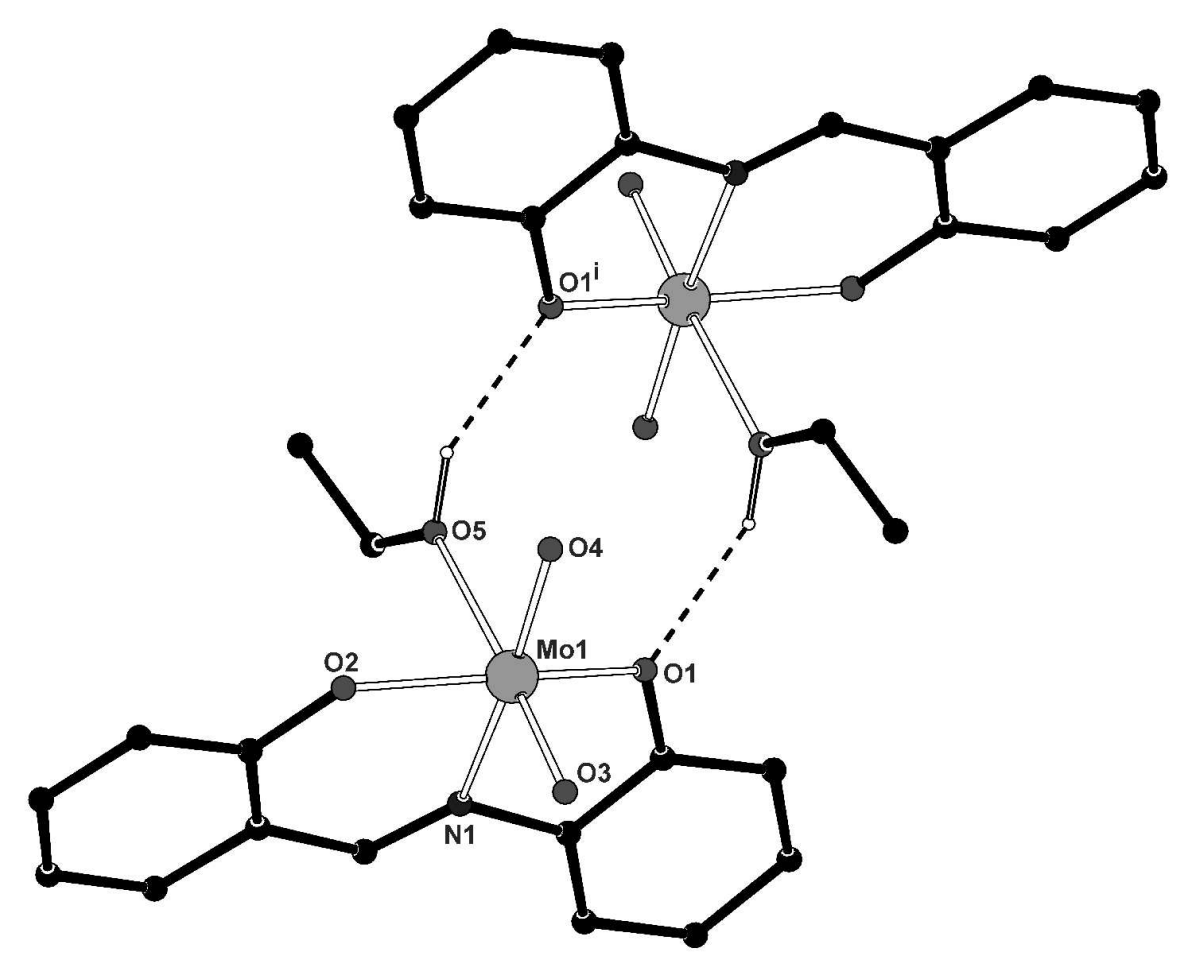

Figure 3. View of a pseudo-dimer formed through hydrogen bonding between two $\mathrm{MoO}_{2}(\mathrm{SAP})(\mathrm{EtOH})$ molecules. Intermolecular hydrogen bonds are represented by dotted lines. $138 \times 102 \mathrm{~mm}(600 \times 600 \mathrm{DPI})$ 
Figure 4. Thermogravimmetric diagram of $\mathrm{MoO}_{2}(\mathrm{SAP})(\mathrm{EtOH})$ $254 \times 190 \mathrm{~mm}(96 \times 96 \mathrm{DPI})$ 
Figure 5. Enthalpy diagram for the conversion of $\mathrm{MoO}_{2} \mathrm{~L}(\mathrm{EtOH})$ to $\left[\mathrm{MoO}_{2} \mathrm{~L}\right]_{2}$ in the gas phase $(\mathrm{L}=$ SAP, SAE).

$254 \times 190 \mathrm{~mm}$ (96 x 96 DPI) 